\title{
THE RÔLE OF THE EPIDIDYMIS AND DUCTUS DEFERENS IN THE DIRECT AND UNILATERAL CONTROL OF THE PROSTATE AND SEMINAL VESICLES OF THE RAT
}

\author{
G. G. PIERREPOINT, P. DAVIES AND D. W. WILSON \\ Tenovus Institute for Cancer Research, Welsh National School of Medicine, \\ The Heath, Cardiff CF4 $4 X X$
}

(Received 29th April 1974)

\begin{abstract}
Summary. Unilateral castration and unilateral vasectomy both bring about a reduction in the androgen-dependent activity of the RNA polymerase enzymes of the ipsilateral lobes of the prostate and seminal vesicles compared to that of the equivalent organs on the contralateral side. After unilateral orchidectomy (i.e. the epididymis was not removed with the testis), the ipsilateral lobes of the prostate were maintained at the same level of activity as those on the intact side. The epididymides, in the absence of the testes but maintained by exogenous testosterone, sustained the prostate and seminal vesicles at a level not achieved in their absence. The epididymis, in the absence of the ipsilateral gonad but maintained by the contralateral testis, provided a greater sustaining influence on the prostate and seminal vesicles than did the testis and epididymis separated from the target organs by vasoligation.

The evidence suggests that the epididymides are able to modulate the function of the prostate and seminal vesicles and that this influence is achieved through an intact ductus deferens. The unilateral effect of castration would seem not to be due solely to the removal of the testis but rather to the simultaneous excision of the androgen-maintained epididymis.
\end{abstract}

\section{INTRODUCTION}

Unilateral castration of the fetus has been shown to restrict the development of the ipsilateral genital structures suggesting that the testicular secretion is not distributed to the general circulation but achieves a local effect by some migratory process along the genital tract (Jost, 1947, 1953). A similar local testicular effect has been shown for epididymal growth in early post-natal life in the rat (Suzuki, Toshimori \& Mochizuki, 1955). For the domestic hen, however, evidence is available to show that the presence of only one testis will assure the normal development of the contralateral epididymis (Maraud \& Stoll, 1960; Stoll \& Maraud, 1968). 
Skinner \& Rowson (1968a, b) concluded from their vasectomy studies in the ram that some testosterone must normally pass along the ductus deferens in the testicular fluid to influence the development and function of the ampulla.

It has been proposed (Pierrepoint, 1974) that in the adult animal organs such as the prostate and seminal vesicles may benefit from a direct transportation of androgenic hormones. This hypothesis was supported by the demonstration of reduced prostatic RNA polymerase (nucleoside triphosphate-RNA nucleotidyltransferase, EC 2.7.7.6) activity after vasectomy and the preferential uptake by the seminal vesicles and prostatic lobes of isotopically-labelled testosterone when infused along the ductus deferens compared with that received through the general circulation (Pierrepoint \& Davies, 1973; Pierrepoint, 1974).

The experiments described in this report give further support to the hypothesis of a direct and unilateral androgenic control of the prostate and seminal vesicles and also provide evidence for the promotion of this influence by the epididymis.

\section{MATERIALS AND METHODS}

The rats used were Sprague-Dawley of the Charles River, U.K. strain between 10 and 19 weeks of age. They were caged in groups of three or four with freely available food and water and were exposed daily to $12 \mathrm{hr}$ light and $12 \mathrm{hr}$ dark. Anaesthesia was induced by either an intraperitoneal injection of $50 \mathrm{mg}$ Themalon (diethylthiambutene hydrochloride: Burroughs Wellcome) in $2 \mathrm{ml}$ Nembutal (pentobarbitone sodium: Abbot Labs, $60 \mathrm{mg} / \mathrm{ml}$ ), or with ether depending upon the anticipated length of the operative procedure. Experimental and control animals received the same anaesthetic.

\section{Purification of nuclei and measurement of $R \mathcal{N} A$ polymerase activity in intact nuclei}

Purified nuclear fractions were prepared from prostatic lobes and from seminal vesicles as described elsewhere (Pierrepoint \& Davies, 1973). Before homogenization in $0.25 \mathrm{M}$-sucrose containing $1 \mathrm{~mm}-\mathrm{MgCl}_{2}$, seminal vesicles were cut open and the secretions were removed by several washes in this medium. Estimation of nuclear RNA polymerase under low- and high-salt conditions by measurement of incoporation of $\left[{ }^{14} \mathrm{C}\right]$ UMP into acid-insoluble material has also been previously described (Davies \& Griffiths, 1973).

\section{Chemical analyses}

The DNA content of the preparations was determined by the diphenylamine procedure of Burton (1956) as modified by Giles \& Myers (1965), using calf thymus DNA (British Drug Houses) as standard. The RNA content was assessed by the orcinol method (Schneider, 1957), using yeast RNA (B.D.H.) as reference.

Plasma testosterone levels were measured by the radioimmunoassay technique described by Hillier, Brownsey \& Cameron (1973), which uses a chromatographic step and an anti-(testosterone-3-BSA) serum raised in rabbits. 
Experimental design

Our earlier investigations showed that vasoligation caused a dramatic fall in the RNA polymerase activity of the rat prostate (Pierrepoint \& Davies, 1973; Pierrepoint, 1974). This finding raised two questions: (a) is there a unilateral control of the prostate and seminal vesicles which is achieved directly through the ductus deferens; (b) to what extent does the epididymis, as the immediate organ to be separated from the prostatic complex following vasectomy, participate in the normal androgenic control of the more distal target organs?

The first question was investigated in two parts, firstly by unilateral castration and secondly by unilateral vasectomy.

The second question was examined by comparing the prostates of animals maintained on androgen after 'total' castration (i.e. orchido-epididymectomy) with those following 'incomplete' castration (orchidectomy only) on the same maintenance regimen. This procedure was then confined to the single animal by unilateral 'incomplete' castration so that differences noted in the ipsi- and contralateral lobes of the target organs could be assigned to local rather than general effects brought about by the surgical interventions.

The surgical procedures adopted are shown schematically in Text-fig. 1.

(a)
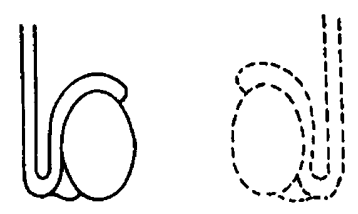

(b)
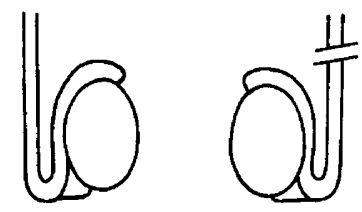

(c)
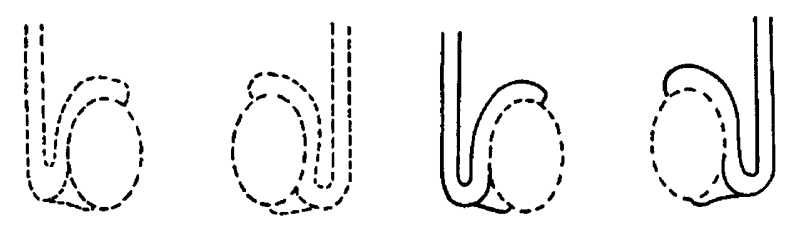

(d)

(e)
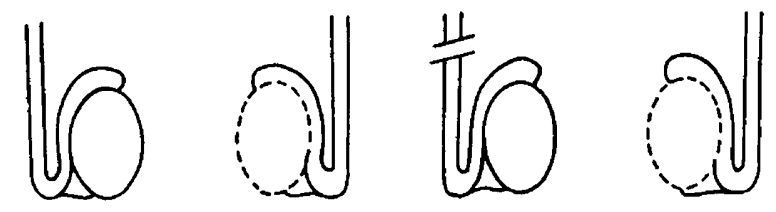

Text-FIG. 1. Schematic representation of the surgical procedures used. (a) Exp. I, unilateral 'total' castration; (b) Exp. II, unilateral vasectomy; (c) Exp. III i, ii and iii, 'total' castration compared with 'incomplete' castration; (d) Exp. IV, unilateral 'incomplete' castration; (e) Exp. V, unilateral 'incomplete' castration with contralateral vasectomy. 
In most cases, nine animals were used and, following a suitable postoperative period, the lobes of the requisite target organs were carefully excised and grouped randomly in sets of three, according to side and organ, to provide sufficient tissue for the assay.

Experiment I. A left-sided 'total' castration was performed on nine rats. The animals were killed 2 weeks later and the left and right lobes of the seminal vesicles and dorsolateral prostates were removed for assay.

Experiment II. A unilateral (left-sided) vasectomy was performed on nine rats as described previously (Pierrepoint, 1974). The ipsi- and contralateral lobes of the seminal vesicles and prostate were removed and assayed 2 weeks later. The experiment was then repeated by ligating the right ductus deferens.

Experiment III. Eighteen rats were allocated equally to three groups. Three animals from each group were subjected to bilateral 'total' castration and the remaining three to bilateral 'incomplete' castration. Each group was then maintained, respectively, on subcutaneous injections of $100 \mu \mathrm{g}$ testosterone, $500 \mu \mathrm{g}$ testosterone and $500 \mu \mathrm{g}$ testosterone propionate, given daily for 5 days. Before death, heart blood was removed from the third group for testosterone analysis. The ventral prostates were taken and assayed as before.

Experiment $I V$. Nine rats were each subjected to unilateral 'incomplete' castration. The ipsi- and contralateral lobes of the prostate and seminal vesicles were removed and assayed in groups of three 4 weeks later.

Experiment $V$. The left testis was removed from nine rats and, at the same time, the right ductus deferens was ligated. The various lobes of the prostate and the seminal vesicles were removed and assayed in groups of three 2 weeks later.

In order to take into account any natural differences occurring in left and right lobes of these bilaterally symmetrical target organs, the dorsolateral and ventral prostates, and seminal vesicles were removed from nine intact rats, within the same age-range as those in the experiments described. The tissues were compared as in the experimental groups. The inherent difference in RNA polymerase activity between opposing lobes of each organ was then incorporated into the statistical analysis of those differences achieved following the surgical ablations.

\section{Statistical analysis of results}

A one-way analysis of variance was carried out on the weights of the 'pooled' organs and on the DNA and RNA contents. In the case of the RNA polymerase activities, a three-way analysis was performed on all results with triplicate determinations within each cell and the findings were evaluated by comparison with those values found normally in intact animals. The main effects were: different pools of tissue $(\mathrm{A}=3)$ selected at random; different treatments, i.e. groups of operated or intact animals $(\mathbf{B}=2)$; and the relationship of the organ to the side of surgery $(\mathrm{C}=2)$. The sums of squares, degrees of freedom, mean of squares and F-ratios were calculated from the source of variation due to main effects, first and second order interactions and from residual variation. The corresponding $P$ values were obtained from Tables. The RNA polymerase activities of the organs from the control rats were assayed at a different time to those from rats subjected to operation thus necessitating normalization of the 
control results. This allowed an assessment to be made of any differences brought about by surgical intervention as opposed to those occurring naturally.

\section{RESULTS}

The effect of unilateral 'total' castration on the ipsi- and contralateral lobes of the dorsolateral prostate and seminal vesicles of rats in Exp. I is shown in Table 1. There was a reduction in the weights of the structures ipsilateral to the operation and especially in the RNA polymerase activity and RNA content of the organs on that side. The DNA content showed little change. Table 2 shows the changes that occurred in these organs following unilateral vasectomy (Exp. II). A highly significant decrease occurred in the RNA polymerase activity as well as in RNA content in those structures ipsilateral to the leftsided vasectomy (Table $2 a$ ). The enzyme activity was similarly affected when the right ductus was ligated although the content of nucleic acids remained constant (Table $2 b$ ).

The results of the three experiments to determine the effect of the presence or absence of the epididymides on the prostate and seminal vesicles of orchidectomized rats maintained on androgens (Exp. III, i, ii and iii) are shown in Table 3. There was an increase in the weight, RNA content and activity of the RNA polymerase enzyme of the ventral prostates with increased dosage of testosterone and the use of the long-acting testosterone derivative but, in each case, these parameters were enhanced when the epididymides were present. Plasma testosterone levels (mean \pm S.D.) in the animals maintained on $500 \mu \mathrm{g}$ testosterone propionate daily in Exp. III, iii were as follows: 'incomplete' castration $606 \cdot 3 \pm 223 \cdot 4 \mathrm{ng} / 100 \mathrm{ml}$; 'total' castration $274 \cdot 0 \pm 9 \cdot 5 \mathrm{ng} / 100 \mathrm{ml}$.

The results of Experiment IV show that there was no significant difference in the activity of the left and right lobes of the dorsolateral and ventral prostate following unilateral orchidectomy (Table 4). The seminal vesicles on the side of the operation had relatively higher levels of function in terms of weight,

Table 1. The effect of unilateral 'total' castration (orchido-epididymectomy) on the RNA polymerase activity, weight and DNA and RNA content of the ipsi- and contralateral lobes of dorsolateral prostate and seminal vesicles of rats (Exp. I)

\begin{tabular}{|c|c|c|c|}
\hline & Intact side & Castrated side & $\mathbf{P}$ values \\
\hline $\begin{array}{l}\text { Dorsolateral prostate } \\
\text { Total wt }(\mathrm{g}) \\
\text { DNA (mg/g) } \\
\text { RNA (mg/g) } \\
\text { RNA polymerase } \\
\text { (pmol }\left[{ }^{14} \mathrm{C}\right] \mathrm{UMP} / 100 \mu \mathrm{g} \text { DNA) }\end{array}$ & $\begin{array}{r}1.27 \pm 0.058 \\
1.57 \pm 0.091 \\
1.74 \pm 0.101 \\
17.69 \pm 1.307\end{array}$ & $\begin{array}{r}1 \cdot 18 \pm 0.076 \\
1 \cdot 61 \pm 0 \cdot 124 \\
1 \cdot 39 \pm 0.137 \\
11 \cdot 18 \pm 0.544\end{array}$ & $\begin{array}{l}\text { N.S. } \\
\text { N.S. } \\
<0.02 \\
<0.001 *\end{array}$ \\
\hline $\begin{array}{l}\text { Seminal vesicles } \\
\text { Total wt (g) } \\
\text { DNA (mg/g) } \\
\text { RNA (mg/g) } \\
\text { RNA polymerase } \\
\text { (pmol [ }{ }^{14} \text { C]UMP/100 } \mu \mathrm{g} \text { DNA) }\end{array}$ & $\begin{array}{r}0.83 \pm 0.076 \\
2 \cdot 11 \pm 0.130 \\
2 \cdot 37 \pm 0.356 \\
15 \cdot 16 \pm 0.310\end{array}$ & $\begin{array}{l}0.68 \pm 0 \cdot 029 \\
2 \cdot 16 \pm 0 \cdot 030 \\
1 \cdot 82 \pm 0 \cdot 165 \\
4 \cdot 46 \pm 0 \cdot 071\end{array}$ & $\begin{array}{l}<0.05 \\
\text { N.S. } \\
<0.07 \\
<0.001^{*}\end{array}$ \\
\hline
\end{tabular}

Values expressed as means \pm S.D. N.S., not significant.

* Assessed by a three-way analysis of variance. 
Table 2. The effect of unilateral vasectomy on the RNA polymerase activity, the weight, and DNA and RNA content of the ipsi- and contralateral lobes of the ventral and dorsolateral prostate and the seminal vesicles of rats (Exp. II)

\begin{tabular}{|c|c|c|c|}
\hline (a) & Intact side $(R)$ & Vasectomized side $(L)$ & P values \\
\hline $\begin{array}{l}\text { Dorsolateral prostate } \\
\text { Total wt }(g) \\
\text { DNA (mg/g) } \\
\text { RNA (mg/g) } \\
\text { RNA polymerase } \\
\left.\text { (pmol [ }{ }^{14} \mathrm{C}\right] \mathrm{UMP} / 100 \mu \mathrm{g} \text { DNA) }\end{array}$ & $\begin{array}{r}1.05 \pm 0 \cdot 100 \\
1.659 \pm 0 \cdot 119 \\
1.897 \pm 0 \cdot 069 \\
12.87 \pm 0.290\end{array}$ & $\begin{array}{cc}1.05 & \pm 0.150 \\
1.532 & \pm 0.064 \\
1.452 & \pm 0.134 \\
10.89 & \pm 0.752\end{array}$ & $\begin{array}{l}\text { N.S. } \\
\text { N.S. } \\
<0.007 \\
<0.001 *\end{array}$ \\
\hline $\begin{array}{l}\text { Ventral prostate } \\
\text { Total wt (g) } \\
\text { DNA (mg/g) } \\
\text { RNA (mg/g) } \\
\text { RNA polymerase } \\
\text { (pmol }\left[{ }^{14} \mathrm{C}\right] \mathrm{UMP} / 100 \mu \mathrm{g} \text { DNA) }\end{array}$ & $\begin{array}{c}1.37 \pm 0.08 \\
1.845 \pm 0.052 \\
1.912 \pm 0.100 \\
19.03 \pm 0.742\end{array}$ & $\begin{array}{cc}1.23 & \pm 0.03 \\
1.793 & \pm 0.077 \\
1.511 & \pm 0.281 \\
16.21 & \pm 0.895\end{array}$ & $\begin{array}{l}<0.05 \\
\text { N.S. } \\
<0.08 \\
<0.001 *\end{array}$ \\
\hline $\begin{array}{l}\text { Seminal vesicles } \\
\text { Total wt }(g) \\
\text { DNA (mg/g) } \\
\text { RNA (mg/g) } \\
\text { RNA polymerase } \\
\text { (pmol }\left[{ }^{14} \mathrm{C}\right] \text { UMP/100 } \mu \mathrm{g} \text { DNA) }\end{array}$ & $\begin{array}{l}1.00 \pm 0.05 \\
2.005 \pm 0.054 \\
2.231 \pm 0.207 \\
5.54 \pm 0.285\end{array}$ & $\begin{array}{ll}0.98 & \pm 0.10 \\
1.886 & \pm 0.077 \\
1.787 & \pm 0.098 \\
5.02 & \pm 0.033\end{array}$ & $\begin{array}{c}\text { N.S. } \\
<0.09 \\
<0.03 \\
0.025>P \\
>0.01^{*}\end{array}$ \\
\hline (b) & Intact side $(L)$ & Vasectomized side $(R)$ & $\mathbf{P}$ values \\
\hline $\begin{array}{l}\text { Dorsolateral prostate } \\
\text { Total wt }(\mathrm{g}) \\
\text { DNA (m/g) } \\
\text { RNA (mg/g) } \\
\text { RNA polymerase } \\
\left.\text { (pmol [ }{ }^{3} \mathrm{H}\right] \mathrm{UTP} / 100 \mu \mathrm{g} \text { DNA) }\end{array}$ & $\begin{array}{l}0.65 \pm 0 \cdot 100 \\
1 \cdot 870 \pm 0 \cdot 0995 \\
3 \cdot 747 \pm 0 \cdot 2670 \\
9 \cdot 199 \pm 0.5179\end{array}$ & $\begin{array}{l}0.617 \pm 0.029 \\
1.739 \pm 0.092 \\
3.391 \pm 0.2601 \\
7.051 \pm 0.8277\end{array}$ & $\begin{array}{l}\text { N.S. } \\
\text { N.S. } \\
\text { N.S. } \\
<0.001 *\end{array}$ \\
\hline $\begin{array}{l}\text { Ventral prostate } \\
\text { Total wt (g) } \\
\text { DNA (mg/g) } \\
\text { RNA (mg/g) } \\
\text { RNA polymerase } \\
\left.\text { (pmol [ }{ }^{3} \mathrm{H}\right] \mathrm{UTP} / 100 \mu \mathrm{g} \text { DNA) }\end{array}$ & $\begin{array}{l}0 \cdot 85 \pm 0 \cdot 05 \\
1 \cdot 980 \pm 0 \cdot 1356 \\
3 \cdot 334 \pm 0 \cdot 4601 \\
8 \cdot 716 \pm 0.7569\end{array}$ & $\begin{array}{ll}0.73 & \pm 0.029 \\
2.021 & \pm 0.263 \\
3.307 & \pm 0.324 \\
7.091 & \pm 0.5514\end{array}$ & $\begin{array}{l}\text { 0.015 } \\
\text { N.S. } \\
\text { N.S. } \\
<0.001^{*}\end{array}$ \\
\hline $\begin{array}{l}\text { Seminal vesicles } \\
\text { Total wt (g) } \\
\text { DNA (mg/g) } \\
\text { RNA (mg/g) } \\
\text { RNA polymerase } \\
\text { (pmol }\left[{ }^{3} \mathrm{H}\right] \text { UTP/100 } \mu \mathrm{g} \text { DNA) }\end{array}$ & $\begin{array}{l}0.50 \pm 0.05 \\
1 \cdot 614 \pm 0 \cdot 0217 \\
3 \cdot 202 \pm 0.0979 \\
8.979 \pm 1.0905\end{array}$ & $\begin{array}{l}0.383 \pm 0.029 \\
1 \cdot 714 \pm 0.1673 \\
3 \cdot 199 \pm 0.0535 \\
6.225 \pm 0.2452\end{array}$ & $\begin{array}{l}<0.015 \\
\text { N.S. } \\
\text { N.S. } \\
<0.001^{*}\end{array}$ \\
\hline
\end{tabular}

Values expressed as means \pm S.D. N.S., not significant. $L=$ left $; R=$ right.

* Assessed by a three-way analysis of variance.

RNA content and RNA polymerase activity compared to those from the 'total' unilateral castration experiment (Exp. I, Table 1) but did not quite reach equality with those of the intact side.

The results of Exp. V combining unilateral 'incomplete' castration with contralateral vasectomy are shown in Table 5.

The content of RNA and the levels of activity of the RNA polymerase of the seminal vesicles and dorsolateral prostate of the castrated side were significantly higher than those from the equivalent organs on the vasectomized side. All the ventral prostate parameters measured showed no significant difference between sides.

The parameters measured in the left and right lobes of the prostate and seminal vesicles from intact animals are shown in Table 6. 
Table 3. The effect of the presence or absence of the epididymides on RNA polymerase activity, weight, DNA and RNA content of the ventral prostate of androgenmaintained castrated rats

\begin{tabular}{|c|c|c|c|}
\hline & $\begin{array}{c}\text { Epididymides } \\
\text { absent }\end{array}$ & $\begin{array}{c}\text { Epididymides } \\
\text { present }\end{array}$ & $\mathbf{P}$ values \\
\hline $\begin{array}{l}\text { Exp. III i (100 } \mu \text { g testosterone/day) } \\
\text { Total wt (g) } \\
\text { DNA (mg/g) } \\
\text { RNA (mg/g) } \\
\text { RNA polymerase } \\
\text { (pmol [ }{ }^{14} \text { C]UMP/100 } \mu \text { g DNA) }\end{array}$ & $\begin{array}{l}0.7 \\
0.969 \\
0.836 \\
18.351\end{array}$ & $\begin{array}{c}1 \cdot 1 \\
0 \cdot 709 \\
1 \cdot 043 \\
29 \cdot 508\end{array}$ & \\
\hline $\begin{array}{l}\text { Exp. III ii (500 } \mu \text { g testosterone/day) } \\
\text { Total wt (g) } \\
\text { DNA (mg/g) } \\
\text { RNA (mg/g) } \\
\text { RNA polymerase } \\
\text { (pmol [ }{ }^{14} \text { C]UMP/100 } \mu \text { gNA) }\end{array}$ & $\begin{array}{c}1 \cdot 6 \\
1 \cdot 31 \\
0.978 \\
28 \cdot 033\end{array}$ & $\begin{array}{c}1 \cdot 7 \\
1 \cdot 04 \\
1 \cdot 236 \\
40 \cdot 198\end{array}$ & \\
\hline $\begin{array}{l}\text { Exp. III iii (500 } \mu \text { g testosterone } \\
\text { propionate/day) } \\
\text { Total wt (g) } \\
\text { DNA (mg/g) } \\
\text { RNA (mg/g) } \\
\text { RNA polymerase } \\
\text { (pmol [ }{ }^{14} \text { C]UMP/100 } \mu \mathrm{g} \text { DNA) }\end{array}$ & $\begin{array}{l}2 \cdot 2 \\
1 \cdot 42 \pm 0.096 \\
1 \cdot 14 \pm 0 \cdot 024 \\
37 \cdot 20 \pm 2 \cdot 703\end{array}$ & $\begin{array}{l}2.3 \\
1.42 \pm 0.202 \\
1.47 \pm 0.140 \\
53.52 \pm 3.556\end{array}$ & $\begin{aligned} & \text { N.S. } \\
& \text { N.S. } \\
&<0.02 \\
&<0.001\end{aligned}$ \\
\hline
\end{tabular}

Values for DNA, RNA and RNA polymerase in Exp. III iii expressed as means \pm S.D. N.S., not significant.

Table 4. The effect of unilateral orchidectomy (epididymis left in situ) on the RNA polymerase activity, weight and DNA and RNA content of the ipsi- and contralateral lobes of the dorsolateral prostate and seminal vesicles in rats (Exp. IV)

\begin{tabular}{|c|c|c|c|}
\hline & Intact side $(R)$ & $\begin{array}{l}\text { Orchidectomized } \\
\quad \text { side }(L)\end{array}$ & P values \\
\hline $\begin{array}{l}\text { Dorsolateral prostate } \\
\text { Total wt (g) } \\
\text { DNA (mg/g) } \\
\text { RNA (mg/g) } \\
\text { RNA polymerase } \\
\left.\text { (pmol [ }{ }^{14} \mathrm{C}\right] \mathrm{UMP} / 100 \mu \mathrm{g} \text { DNA) }\end{array}$ & $\begin{array}{l}0.9 \pm 0.10 \\
1.365 \pm 0.067 \\
1.742 \pm 0.083 \\
19.11 \pm 1.177\end{array}$ & $\begin{array}{c}0.85 \pm 0.09 \\
1.390 \pm 0.051 \\
1.285 \pm 0.146 \\
20.11 \pm 2.029\end{array}$ & $\begin{array}{c}\text { N.S. } \\
\text { N.S. } \\
<0.009 \\
\text { N.S.* }\end{array}$ \\
\hline $\begin{array}{l}\text { Seminal vesicles } \\
\text { Total wt }(\mathrm{g}) \\
\text { DNA (mg/g) } \\
\text { RNA (mg/g) } \\
\text { RNA polymerase } \\
\text { (pmol }\left[{ }^{14} \mathrm{C}\right] \mathrm{UMP} / 100 \mu \mathrm{g} \text { DNA) }\end{array}$ & $\begin{array}{c}1.05 \pm 0.13 \\
2 \cdot 143 \pm 0.099 \\
2.507 \pm 0.107 \\
14.85 \pm 0.161\end{array}$ & $\begin{array}{c}0.88 \pm 0.10 \\
2 \cdot 185 \pm 0.025 \\
2.329 \pm 0.089 \\
10.74 \pm 0.173\end{array}$ & $\begin{array}{l}<0.09 \\
\text { N.S. } \\
<0.09 \\
<0.001^{*}\end{array}$ \\
\hline $\begin{array}{l}\text { Ventral prostate } \\
\text { Total wt (g) } \dagger \\
\text { DNA (mg/g) } \\
\text { RNA (mg/g) } \\
\text { RNA polymerase } \\
\text { (pmol }\left[{ }^{14} \mathrm{C}\right] \mathrm{UMP} / 100 \mu \mathrm{g} \text { DNA) }\end{array}$ & $\begin{array}{r}1.754 \pm 0.106 \\
1.910 \pm 0.088 \\
11.89 \pm 0.919\end{array}$ & $\begin{array}{r}-\overline{1.773 \pm 0.133} \\
1.570 \pm 0.221 \\
12.15 \pm 1.565\end{array}$ & $\begin{array}{r}\text { N.S. } \\
<0.12 \\
\text { N.S.* }\end{array}$ \\
\hline
\end{tabular}

Values expressed as means \pm S.D. N.S., not significant. $R=$ right; $L=$ left.

* Assessed by a three-way analysis of variance.

$\uparrow$ Weights recorded but record subsequently mislaid. 
Table 5. The effect of unilateral orchidectomy (ipsilateral epididymis left in situ) and contralateral vasectomy on the RNA polymerase activity, weight and DNA and RNA content of the two sets of prostatic and seminal vesicle lobes in rats (Exp. V)

\begin{tabular}{|c|c|c|c|}
\hline & $\begin{array}{l}\text { Vasectomized } \\
\text { side }(R)\end{array}$ & $\begin{array}{l}\text { Orchidectomized } \\
\text { side }(L)\end{array}$ & P values \\
\hline $\begin{array}{l}\text { Dorsolateral prostate } \\
\text { Total wt (g) } \\
\text { DNA (mg/g) } \\
\text { RNA (mg/g) } \\
\text { RNA polymerase } \\
\text { (pmol [ }{ }^{14} \text { C]UMP/100 } \mu \mathrm{g} \text { DNA) }\end{array}$ & $\begin{array}{l}1.19 \pm 0.055 \\
1.81 \pm 0.069 \\
1.46 \pm 0.071 \\
8.57 \pm 0.330\end{array}$ & $\begin{array}{r}1.23 \pm 0.029 \\
1.88 \pm 0.051 \\
1.85 \pm 0.079 \\
12.30 \pm 0.263\end{array}$ & $\begin{array}{l}\text { N.S. } \\
\text { N.S. } \\
<0.005 \\
<0.001 *\end{array}$ \\
\hline $\begin{array}{l}\text { Ventral prostate } \\
\text { Total wt (g) } \\
\text { DNA (mg/g) } \\
\text { RNA (mg/g) } \\
\text { RNA polymerase } \\
\left.\text { (pmol [ }{ }^{14} \mathrm{C}\right] \mathrm{UMP} / 100 \mu \mathrm{g} \text { DNA) }\end{array}$ & $\begin{array}{r}1.43 \pm 0.104 \\
1.89 \pm 0.042 \\
1.87 \pm 0.044 \\
10.86 \pm 0.567\end{array}$ & $\begin{array}{r}1.43 \pm 0.029 \\
1.92 \pm 0.068 \\
1.89 \pm 0.053 \\
10.75 \pm 0.102\end{array}$ & $\begin{array}{l}\text { N.S. } \\
\text { N.S. } \\
\text { N.S. } \\
\text { N.S.* }\end{array}$ \\
\hline $\begin{array}{l}\text { Seminal vesicles } \\
\text { Total wt (g) } \\
\text { DNA (mg/g) } \\
\text { RNA (mg/g) } \\
\text { RNA polymerase } \\
\left.\text { (pmol [ }{ }^{14} \mathrm{C}\right] \mathrm{UMP} / 100 \mu \mathrm{g} \text { DNA) }\end{array}$ & $\begin{array}{l}1.10 \pm 0.050 \\
1.73 \pm 0.117 \\
1.26 \pm 0.039 \\
5.94 \pm 0.782\end{array}$ & $\begin{array}{l}1 \cdot 13 \pm 0 \cdot 058 \\
1 \cdot 80 \pm 0 \cdot 112 \\
1 \cdot 93 \pm 0 \cdot 106 \\
9 \cdot 17 \pm 0 \cdot 272\end{array}$ & $\begin{array}{l}\text { N.S. } \\
\text { N.S. } \\
<0.001 \\
<0.001 *\end{array}$ \\
\hline
\end{tabular}

Values expressed as means \pm S.D. N.S., not significant. $R=$ right; $L=$ left.

* Assessed by a three-way analysis of variance.

Table 6. A comparison of natural variation between leftand right-sided lobes of the ventral and dorsolateral prostate and seminal vesicles of intact rats

\begin{tabular}{|c|c|c|}
\hline & Left side & Right side \\
\hline $\begin{array}{l}\text { Dorsolateral prostate } \\
\text { Total wt (g) } \\
\text { DNA (mg/g) } \\
\text { RNA (mg/g) } \\
\text { RNA polymerase } \\
\left.\text { (pmol [ }{ }^{3} \mathrm{H}\right] \mathrm{UTP} / 100 \mu \mathrm{g} \text { DNA) }\end{array}$ & $\begin{array}{r}1.033 \pm 0.116 \\
1.669 \pm 0.084 \\
3.119 \pm 0.082 \\
19.292 \pm 0.949\end{array}$ & $\begin{array}{r}1.00 \pm 0 \cdot 100 \\
1 \cdot 793 \pm 0.056 \\
3 \cdot 167 \pm 0 \cdot 151 \\
18 \cdot 701 \pm 0.683\end{array}$ \\
\hline $\begin{array}{l}\text { Ventral prostate } \\
\text { Total wt (g) } \\
\text { DNA (mg/g) } \\
\text { RNA (mg/g) } \\
\text { RNA polymerase } \\
\left.\text { (pmol [ }{ }^{3} \mathrm{H}\right] \mathrm{UTP} / 100 \mu \mathrm{g} \text { DNA) }\end{array}$ & $\begin{array}{r}1.40 \pm 0.100 \\
1.891 \pm 0.049 \\
3.057 \pm 0.077 \\
18.762 \pm 0.503\end{array}$ & $\begin{array}{r}1.30 \pm 0.10 \\
1.961 \pm 0.046 \\
2.900 \pm 0.059 \\
18.063 \pm 0.533\end{array}$ \\
\hline $\begin{array}{l}\text { Seminal vesicles } \\
\text { Total wt (g) } \\
\text { DNA (mg/g) } \\
\text { RNA (mg/g) } \\
\text { RNA polymerase } \\
\left.\text { (pmol [ }{ }^{3} \mathrm{H}\right] \mathrm{UTP} / 100 \mu \mathrm{g} \text { DNA) }\end{array}$ & $\begin{array}{r}0.80 \pm 0.10 \\
1.446 \pm 0.043 \\
2 \cdot 382 \pm 0.196 \\
22.433 \pm 0.983\end{array}$ & $\begin{array}{r}0.83 \pm 0.058 \\
1.528 \pm 0.078 \\
2.796 \pm 0.174 \\
21.632 \pm 0.825\end{array}$ \\
\hline
\end{tabular}

Values expressed as means \pm S.D. 


\section{DISCUSSION}

The results of Exp. I shown in Table 1 appear to indicate that a unilateral testicular influence such as that shown in the fetus (Jost, 1947, 1953) does exist in the adult. Unilateral 'total' castration reduces the androgen-sensitive activity of the RNA polymerase enzyme system as well as the total wet weight and RNA content of the prostate and seminal vesicles ipsilateral to the operation. Furthermore, the results of Exp. II shown in Table 2 clearly indicate that unilateral vasectomy similarly creates a disparity between the ipsi- and contralateral lobes of the prostate and seminal vesicles irrespective of the side of surgery. The results therefore confirm the original findings of Pierrepoint \& Davies (1973) and Pierrepoint (1974) that vasectomy reduces the activity of the prostate possibly by an interruption in the transfer of androgenic substances. White \& Hudson (1968) have demonstrated the presence of testosterone and dehydroepiandrosterone in the fluid of the male reproductive tract.

The evidence would suggest that circulating levels of androgens in man do not change after vasectomy (Bunge, 1972; Wieland, Hallberg, Zorn, Klein $\&$ Luria, 1972). This is further supported by the unaltered postoperative sexual behaviour observed in man (Nash \& Rich, 1972), and the rhesus monkey (Phoenix, 1973). A reduction in the androgen output of the immature rat has been reported after vasectomy (Sackler, Weltman, Pandhi \& Schwartz, 1973) which does not occur in the adult animal (Plaut, 1973). The ultrastructure of the rat testis is similarly unaffected by vasectomy (Flickinger, 1973).

More far-reaching interpretations can be ascribed to the results derived from Exps III i, ii and iii in which an endocrine function of the epididymides, not hitherto experimentally shown, may be assumed. In these experiments, it has been demonstrated that the prostate and seminal vesicles of orchidectomized rats treated with androgens will be maintained in the presence of the epididymides at a level of activity not achieved in their absence. Measurement of the circulating testosterone levels showed that those castrated rats which possessed epididymides and were maintained on $500 \mu \mathrm{g}$ testosterone propionate daily had higher levels than 'totally' castrated rats on the same regimen (Exp. III iii). This suggests that the androgen-maintained epididymis is capable of synthesizing testosterone. Although this has been demonstrated in vitro (Hamilton \& Fawcett, 1970), the extent to which this apparently occurs in vivo is surprising and supports the view that a stallion castrated without also removing the epididymides will allow the gelding to retain many of the entire animal's masculine propensities (O'Connor, 1950).

Changes in circulating testosterone levels cannot explain, however, the epididymal effect on the RNA polymerase enzyme of the ipsilateral lobes of the prostate and seminal vesicles in unilaterally orchidectomized rats (Exp. IV, Table 4). The ventral and dorsolateral lobes of the prostate of the orchidectomized side were maintained at the level of the intact side merely by the presence of the epididymis maintained by the opposing testis. The effect was less marked in the case of the seminal vesicles, and the lobes ipsilateral to the orchidectomy did not achieve equality with the contralateral gland. The level of activity however was more than double that of rats subjected to unilateral 'total' 
castration (Table 1). This disparity may be due to the difference in sensitivity of the seminal vesicles to androgen levels (Price, 1936; Dorfman, 1962; Fujii \& Villee, 1969) or to some additional dependency on the proximal gonad as well as on the epididymis.

It would appear that the epididymis ipsilateral to the orchidectomy is maintained by the contralateral testis, as demonstrated in the fetus (Maraud \& Stoll, 1960), and then redistributes this androgenic influence to the ipsilateral lobes of the prostate and seminal vesicles. Orgebin-Crist (1973) has recently demonstrated that spermatozoa will mature in an epididymis maintained only by the contralateral testis. This function of the organ, at least, must, therefore, be independent of its own gonad.

The results of Exp. V (Table 5) indicate that the androgen-maintained epididymis with an intact ductus deferens achieves a higher degree of dorsolateral prostatic and seminal vesicle function than does the testis separated from its target organ by vasectomy. In the case of the ventral lobes of the prostate, unilateral vasectomy nullified the effect of contralateral orchidectomy. These results have a remarkable similarity with those of Skinner \& Rowson (1968a) who showed that the reduced androgen-maintaining influence of a cryptorchid testis on the ipsilateral ampulla could be equalized with that of the opposing testis by contralateral vasectomy.

Another possible route of androgen transfer is that of the lymphatic system. This was left intact during surgery but the work of Lindner (1963) in the ram and of Haltmeyer \& Eik-Nes (1974) in the dog has shown that the system may be disregarded when considering androgenic influences on remote target organs.

In conclusion, a unilateral control of the lobes of the dorsolateral and ventral prostate and seminal vesicles in the rat seems to be exerted by the androgenmaintained epididymis rather than by the testis alone. This effect is prevented by vasectomy, and experiments are in progress to determine how this local influence is achieved.

It would be interesting to know whether this epididymal endocrine effect pertains during genital development in the fetus or whether such development is truly a function of the testis.

\section{ACKNOWLEDGMENTS}

The authors wish to acknowledge the generous financial assistance of the Tenovus Organisation in Cardiff and the excellent surgical assistance of Mr D. Mulcuck.

\section{REFERENGES}

Bungr, R. G. (1972) Plasma testosterone levels in man before and after vasectomy. Investve Urol. 10, 9. Burton, K. (1956) A study of the conditions and mechanism of the diphenylamine reaction for the colorimetric estimation of deoxyribonucleic acids. Biochem. F. 62, 315.

Davies, P. \& GRIfrrths, K. (1973) Stimulation of ribonucleic acid polymerase activity in vitro by prostatic steroid-protein complexes. Biochem. F. 136, 611 .

Dorfman, R. I. (1962) Androgens and anabolic agents. In Methods in Hormone Research, Vol. II. Bioassay, p. 305. Ed. R. I. Dorfman. Academic Press, New York and London.

Flickinger, C. J. (1973) Ultrastructure of the rat testis after vasectomy. Anat. Rec. 174, 477. 
FujiI, T. \& VilLEE, C. A. (1969) RNA metabolism in seminal vesicles and prostate of immature rats following castration and androgen replacement. Acta endocr., Copenh. 60, 527.

Giles, K. W. \& Myers, A. (1965) An improved method for the estimation of deoxyribonucleic acid. Nature, Lond. 206, 93.

Haltmeyer, G. G. \& Eik-Nes, K. B. (1974) Transport of $5 \alpha$-dihydrotestosterone by testicular lymph in the dog. 7. Reprod. Fert. 36, 41.

Hamilton, D. W. \& FAWCETT, D. W. (1970) In vitro synthesis of cholesterol and testosterone from acetate by rat epididymis and vas deferens. Proc. Soc. exp. Biol. Med. 133, 693.

Hillier, S. G., Brownsey, B. G. \& GAMERon, E. H. D. (1973) Some observations on the determination of testosterone in human plasma by radioimmunoassay using antiserum raised against testosterone-3-BSA and testosterone-11 $\alpha$-BSA. Steroids, 21, 735.

Jost, A. (1947) Recherches sur la différenciation sexuelle de l'embryon de lapin. Rôle des gonades foetales dans la différenciation sexuelle somatique. Archs Anat. microsc. Morph. exp. 36, 271.

Jost, A. (1953) Problems of foetal endocrinology. The gonadal and hypophyseal hormones. Recent Progr. Horm. Res. 8, 379.

Lindner, H. R. (1963) Partition of androgen between the lymph and venous blood of the testis in the ram. F. Endocr. 25, 483.

Maraud, R. \& Stolt, R. (1960) Sur le rôle inducteur du testicule dans la morphogénèse épididymaire des Vertébrés amniotes. Résultats de la castration unilatérale. C. r. Séanc Soc. Biol. 154, 1798.

NASH, J. L. \& Rich, J. D. (1972) The sexual after-effects of vasectomy. Fert. Steril. 23, 715.

O'Connor, J. J. (1950) Cutting a horse 'proud'. In Dollar's Veterinary Surgery. General, Operative and Regional, Pt II, p. 376, 4th edn. Ed. J. J. O'Connor. Ballière, Tindall \& Cox, London.

ORGEBIN-GRIST, M.-C. (1973) Maturation of spermatozoa in the rabbit epididymis. Effect of castration and testosterone replacement. F. exp. Zool. 185, 301.

Phoenix, C. H. (1973) Sexual behavior in rhesus monkeys after vasectomy. Science, $\mathcal{N} . \Upsilon$. 179, 493.

Pierrepoint, G. G. (1974) Does hormone transfer along the vasa deferentia contribute to the control of prostatic function and could it be a factor in the aetiology of prostatic hyperplasia? In Normal and Abnormal Growth of the Prostate. Ed. M. Goland. (In press).

Pierrepoint, G. G. \& Davies, P. (1973) The effect of vasectomy on the activity of prostatic RNA polymerase in rats. F. Reprod. Fert. 35, 149.

PlaUt, S. M. (1973) Testicular morphology in rats vasectomized as adults. Science, $\mathcal{N} . \Upsilon .181,554$.

PRICE, D. (1936) Normal development of the prostate and seminal vesicles of the rat with a study of experimental post-natal modifications. Am. F. Anat. 60, 79 .

Sackler, A. M., Weltman, A. S., Pandhi, V. \& Schwartz, R. (1973) Gonadal effects of vasectomy and vasoligation. Science, N.Y. 179, 293.

Schneider, W. C. (1957) Determination of nucleic acids in tissues by pentose analysis. In Methods in Enzymology, Vol. III, pp. 680-684. Eds. S. P. Colowick and N. O. Kaplan. Academic Press, New York.

SKInNER, J. D. \& Rowson, L. E. A. (1968a) Some effects of unilateral cryptorchism and vasectomy on sexual development of the pubescent ram and bull. F. Endocr. 42, 311.

Skinner, J. D. \& Rowson, L. E. A. (1968b) Effects of testosterone injected unilaterally down the vas deferens on the accessory glands of the ram. F. Endocr. 42, 355.

Stoll, R. \& Maraud, R. (1968) Bases experimentales d'une conception dualiste de la différenciation sexuelle des gonoducts chez le mâle des vertébrés. Archs Anat. Histol. Embryol. 51, 667.

Suzuki, Y., Toshrmori, Y. \& Mochizuki, K. (1955) Possibility of direct transportation of testicular hormone to some target organs located close to the testicle in the postnatal rat and its physiologic significance. Endocrinology, 56, 347.

Whrte, I. G. \& Hudson, B. (1968) The testosterone and dehydroepiandrosterone concentration in fluids of the mammalian male reproductive tract. F. Endocr. 41, 291.

Wieland, R. G., Hallberc, M. C., Zorn, E. M., KLein, D. E. \& LuRIA, S. S. (1972) Pituitary gonadal function before and after vasectomy. Fert. Steril. 23, 779. 